\title{
The Effects of Lycopene Application on Sodium Fluoride (NaF) Applied Renal Cell Line
}

\author{
Sedat ÇETIN**1, Fatmagül YUR ${ }^{2}$, Mehmet TAŞPINAR ${ }^{3}$, Semiha DEDE ${ }^{1}$, \\ Veysel YÜKSEK ${ }^{4}$
}

\author{
${ }^{1}$ VanYüzüncü Yıl University, Faculty of Veterinary Science, Biochemistry Department, Van \\ ${ }^{2}$ Muğla Sitkı Koçman University, Faculty of Health Sciences, Muğla \\ ${ }^{3}$ VanYüzüncü Y1l University, Faculty of Medicine, Medical Biology Department, Van \\ ${ }^{4}$ VanYüzüncü Yıl University Özalp Vocational School, Van
}

Received: 28 April 2017 - Accepted: 03 June 2017

\begin{abstract}
The present study was planned to investigate the potential protective properties of lycopene, an antioxidant carotenoid, on NaF applied renal cell line. NRK-52E cells were cultured under standard in vitro conditions with regular passages. 10.000 NRK-52E cells were planted in each culture platelet. Cells were incubated for 24 hours at $37^{\circ} \mathrm{C}$ in an incubator with $\mathrm{CO}_{2}$. After the incubation, the medium formed on the cells was removed and the prepared $\mathrm{NaF}$ and lycopene solutions were added. At least 4 wells were used for each dose. Culture vessels were incubated at $37^{\circ} \mathrm{C}$ in a $\mathrm{CO}_{2}$ incubator for 6,12 , and 24 hours for transformation of non-soluble formazan crystals by MTT stain and the MTT assay was conducted. In conclusion, it was found that low lycopene concentrations reduced the toxic effect of $\mathrm{NaF}$ by $10-20 \%$, while lycopene increased the toxic effect of $\mathrm{NaF}$ synergistically in the high concentration lycopene treated groups. Thus, it was concluded that administration of lycopene on $\mathrm{NaF}$ applied renal cell line exhibited different effects based on concentration and duration.
\end{abstract}

Keywords: NaF, Lycopene, Cell Culture, MTT, Kidney.

\section{INTRODUCTION}

Lycopene (Lyc) is a carotene with an acyclic structure and 11 conjugated double bonds, where the double bonds are in all-trans form. Chromophore in the polyene chain provides the molecule with a red color and antioxidant properties [1]. It was reported that Lycopene has several uses due to its anti-inflammatory, anticancer, and antioxidant properties [2]. Lycopene inhibits the inflammatory reactions, regulate slip oxygenase and cyclooxygenase enzymes and inhibits prostaglandin, prostaglandin, thromboxane and leukotriene synthesis [3]. It was reported that lycopene is protective against prostate, uterus and liver cancers, aging, Alzheimer's, and cardiovascular diseases [4]. The kidney is well known as the primary organ for fluoride excretion and retention, and the kidney is a sensitive organ that exhibits histopathological and functional reactions to fluoride overload [5]. Fluoride is a toxic substance

${ }^{*}$ Corresponding Author E-mail: sedatcetin@yyu.edu.tr 
that accumulates in the body. On average, only $50-80 \%$ of the fluoride ingested is excreted by kidneys, and the remainder accumulates in bones, pineal glands and other tissues [6].

\section{MATERIAL and METHODS}

The NRK-52E cells were reproduced in vitro at $37^{\circ} \mathrm{C}$, in a medium that contained $5 \%$ $\mathrm{CO}_{2}$ and $95 \%$ moisture. $10.000 \mathrm{NRK}-52 \mathrm{E}$ cells were cultured in 96-well culture plates. It was determined that the $\mathrm{IC}_{50}$ value for sodium fluoride $(\mathrm{NaF})$ was $6000 \mu \mathrm{M}$ [7]. Cells were incubated for 24 hours at $37^{\circ} \mathrm{C}$ in an incubator with $\mathrm{CO}_{2}$. After the incubation, the medium covering the cells was removed and the previously prepared $\mathrm{NaF}$ and lycopene solutions were added. At least 4 wells were used for each concentration. Culture vessels were incubated at $37^{\circ} \mathrm{C}$ in a $\mathrm{CO}_{2}$ incubator and MTT assay was performed.

\section{RESULTS}

A cell vitality that was higher than the $\mathrm{IC}_{50}$ value was observed based on MTT dose and the time in lycopene applied groups after 6, 12, and 24 hours. The results demonstrated that all lycopene concentrations used in the present study were reliable. In the $\mathrm{NaF}+$ lycopene treated groups, an increase of $12-35 \%$ was observed in cell viability at low concentrations $(1 \mu \mathrm{M}, 2$ $\mu \mathrm{M}, 5 \mu \mathrm{M}, 10 \mu \mathrm{M}$, and $15 \mu \mathrm{M}$ ) (Figure 1). At the 12th and 24th hours, an increase of about $33 \%$ was detected in the groups treated with $\mathrm{NaF}+$ lycopene only at the concentration of $1 \mu \mathrm{M}$ (Figure 2 and 3).

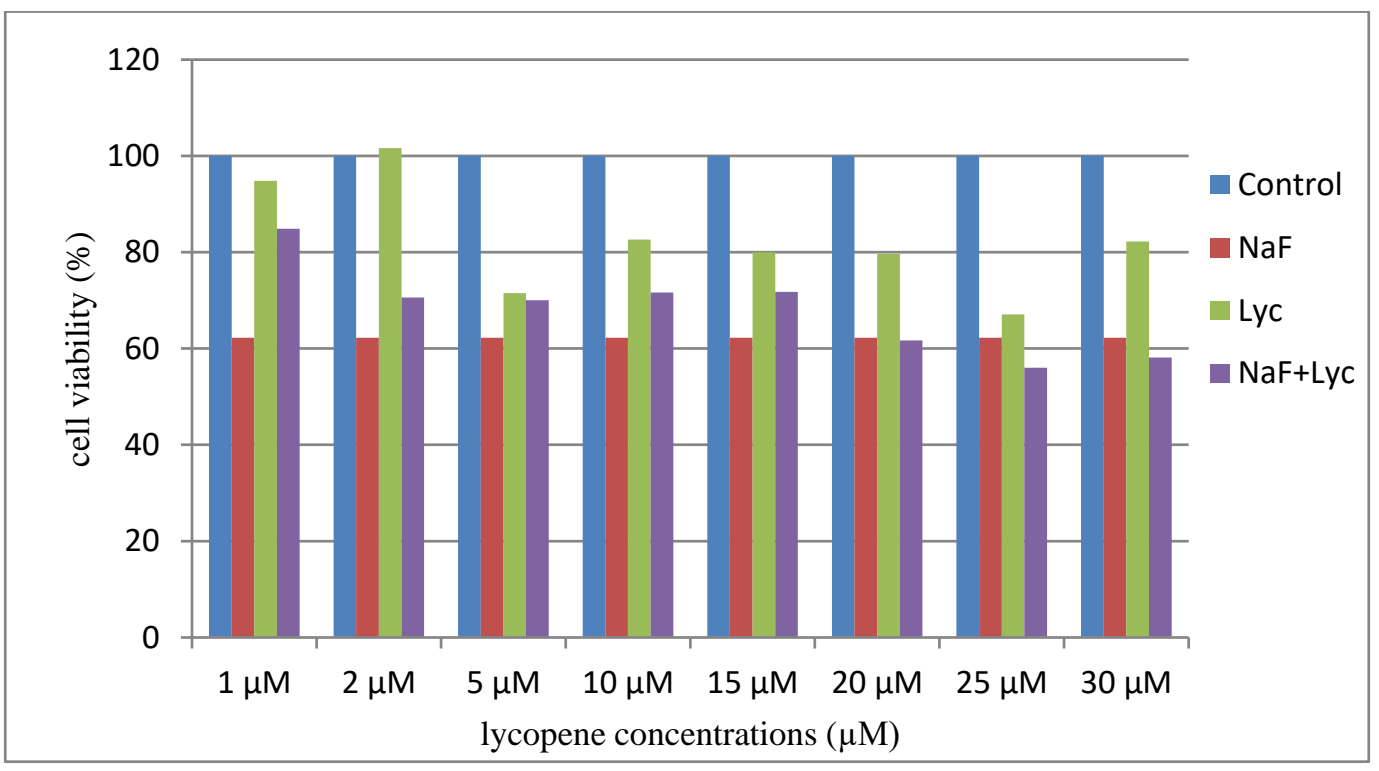

Figure 1. Effect of lycopene on MTT after 6 hours in NRK-52E cells treated with NaF 


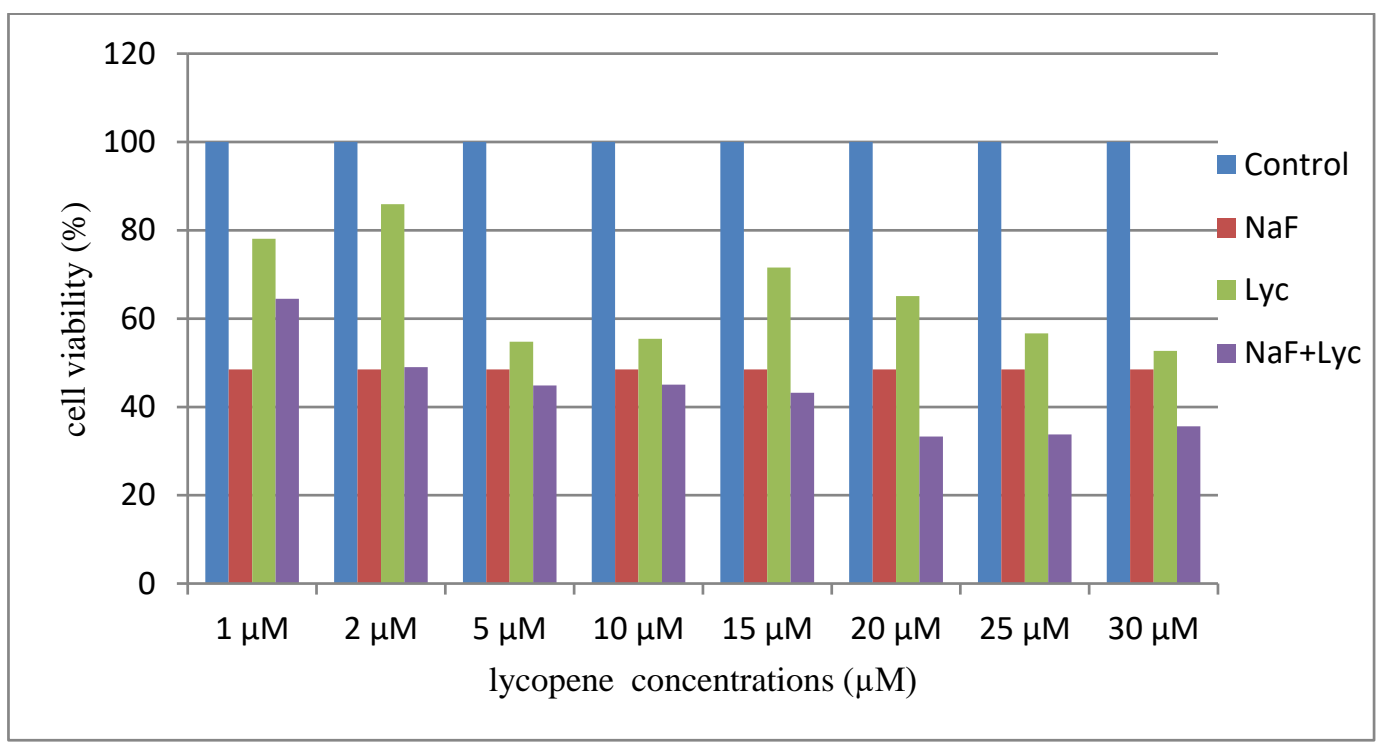

Figure 2. Effect of lycopene on MTT after 12 hours in NRK-52E cells treated with NaF.

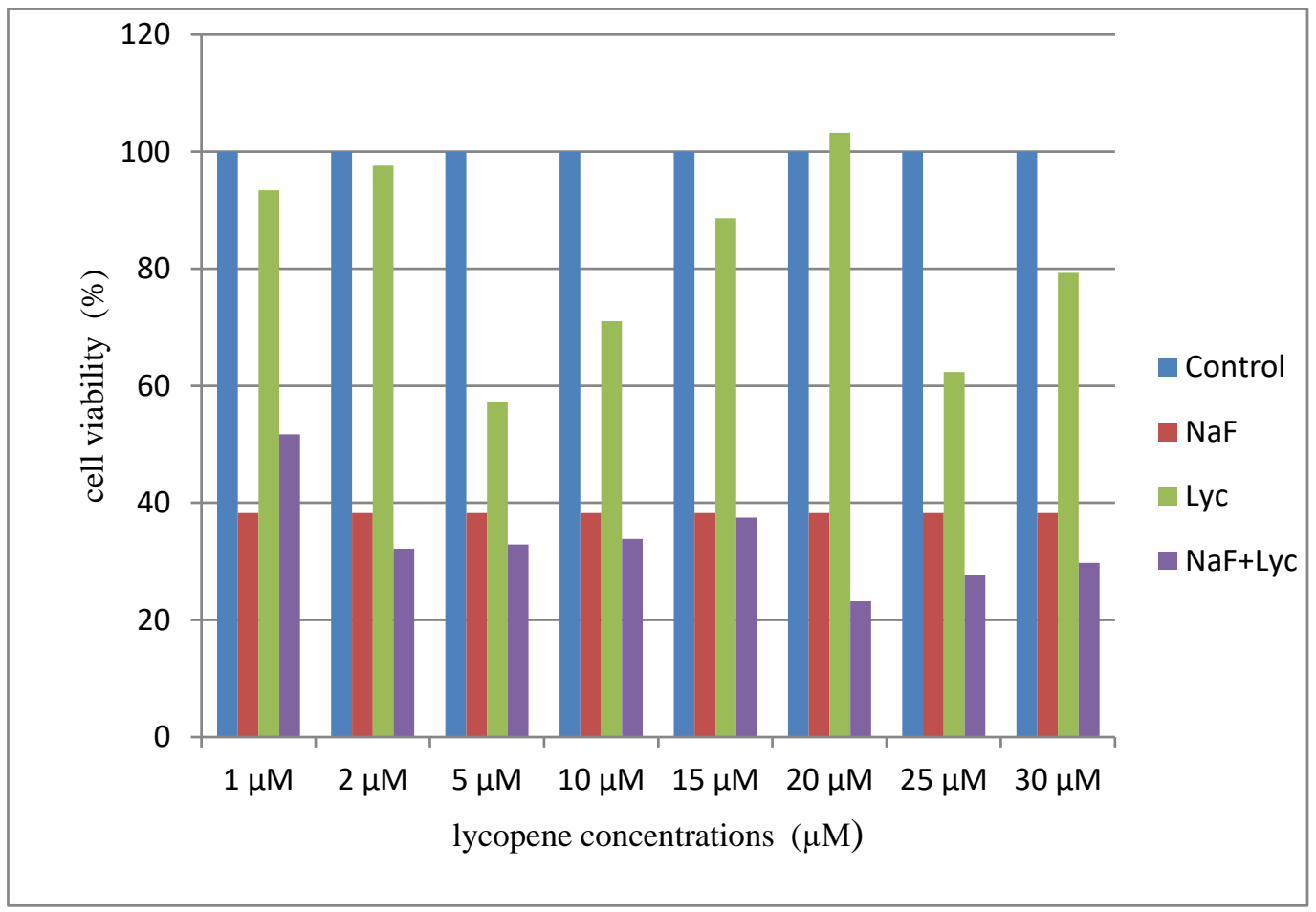

Figure 3. Effect of lycopene on MTT after 24 hours in NRK-52E cells treated with NaF.

\section{DISCUSSION and CONCLUSION}

While lycopene exhibited strong antioxidant properties under in vitro conditions, it also demonstrated protective properties against DNA, protein and lipid oxidation in vivo [8]. Li et al. (2017) reported that lycopene significantly affected NaF-induced ameloblast and tooth fluorosis by reducing oxidative stress and the caspase pathway [9]. Mansour and Tawfik (2012) demonstrated that lycopene administration to NaF-administered rats could reduce the toxic effects of fluoride that characterized the free radical and strong antioxidant activities of the fluoride [10]. 
In the present study, it was determined that low concentrations of lycopene $(1 \mu \mathrm{M}, 2 \mu \mathrm{M}$, $5 \mu \mathrm{M}$ and $10 \mu \mathrm{M})$ reduced the toxic effect of $\mathrm{NaF}$, while in the high concentration lycopene treated groups, it increased $\mathrm{NaF}$ toxicity via its synergistic effect. In conclusion, it was demonstrated that lycopene administration in the renal cell line have different effects based on concentration and duration.

\section{Conflict of Interests}

Authors declare that there is no conflict of interests.

\section{REFERENCES}

[1]. Bramley, P.M. (2000). Is lycopene benefcial to human health? Phytochemistry, 54(3), 233236.

[2]. Agarwal, A., Shen, H., Agarwal, S., \& Rao, A.V. (2001). Lycopene content of tomato products: its stability, bio availability and in vivo antioxidan properties. J Med Food, 4(1), 9-15.

[3]. Pruthi, R.S, Derksen, E., \& Gaston, K.(2003). Cyclooxygenase-2 as a potential target in the prevention and treatment of genitourinary tumors, a review. J Urol, 169(6), 2352-2359.

[4].Mashima, R., Witting, P.K., \& Stocker, R. (2001). Oxidants and antioxidants in atherosclerosis. Curr Opin Lipidol, 12(4), 411-418.

[5]. Xu, H., Hu, L.S., Chang, M., Jing, L., Zhang, X.Y., \& Li, G.S (2005) Proteomic analysis of kidney in fluoride-treated rat. Toxi Lett, 160 (1), 69-75.

[6]. Chouhan, S., \& Flora, S.J. (2008). Effects of fluoride on the tissue oxidative stress and apoptosis in rats: Biochemical assays supported by IR spectroscopy data. Toxicology, 254(1- 2), 61-67.

[7]. Çetin, S. (2017). NaF Application in Renal and Osteoblast Cell Lines. The Effects of Certain Minerals on Apoptosis and DNA Damage. Yuzuncu Y1l University, Institute of Health Sciences, PhD Thesis.

[8]. Matos, H.R., Capelozzi, V.L., Gomes, O.F., Mascio, P.D., \& Medeiros, M.H. (2001). Lycopene inhibitis DNA damage and liver necrosis in rats treated with ferric nitrilotriacetate. Arch Biochem Biophys, 396(2), 171-177.

[9]. Li, W., Jiang, B., Cao, X., Xie, Y., \& Huang, T. (2017). Protective effect of lycopene on fluoride-induced ameloblasts apoptosis and dental fluorosis through oxidative stressmediated Caspase pathways. Chem Biol Interact, 261(5), 27-34.

[10]. Mansour, H.H., \& Tawfik, S.S. (2012). Efficacy of lycopene against fluoride toxicity in rats. Pharm Biol, 50(6), 707-711. 